\title{
Whyte, David (2020). Ecocide: Kill the Corporation Before it Kills Us. Manchester: Manchester University Press, pp. 220. \$14.95. ISBN 978-1-5261-4698-4
}

\author{
Jose Atiles-Osoria ${ }^{1}$ \\ Published online: 8 March 2021 \\ (C) Springer Nature B.V. 2021
}

The Covid-19 global pandemic and the Black Lives Matter (BLM) mobilizations of the summer of 2020 have shed light on the role corporations play in almost every aspect of our daily lives. Under the pretext of reopening the economy, governments around the world have legislated emergency laws and 'business support packages' to bail out airlines companies, auto manufacturers, and the oil industry, while the pharmaceutical industry has led the way in developing vaccines and distributing PPE. Simultaneously, societies are experiencing an economic and humanitarian crisis, particularly affecting incarcerated populations, immigrants, and unhoused populations. Similarly, amidst the BLM mobilizations, multiple corporations, especially big tech, issued statements supporting the movement for racial justice, while maintaining their ties to police foundations and continuing with extractive and exploitative labor practices worldwide. These governmental and corporate responses to the Covid-19 crisis and to the BLM mobilizations exemplify an important paradox: while corporations have been profiting from the aforementioned crisis, they have played a key role in creating and exacerbating the current multilayered climate, economic, political, and humanitarian crisis.

This is one of the key arguments introduced by David Whyte's book, Ecocide: Kill the Corporation Before It Kills Us. Clearly and cleverly written, the book invites readers to rethink the role of law, corporations, and states in manufacturing the climate catastrophe or ecocide that propelled the aforementioned multilayered crisis.

Ecocide recovers the debates on international law and the work of scholars that, in the $1970 \mathrm{~s}$, tried to define a crime of ecocide, in what was later called the Ecocide Convention. Whyte defines ecocide as the deliberate destruction of our natural environment. The term ecocide, captures the entirety of the threats to the sustainability of the planet: climate change, the ravaging of ecosystems, the eradication of species, and the pollution of air, land, and water. Furthermore, Whyte argues that ecocide cannot be averted as long as corporations control the industrial processes wrecking our world.

Jose Atiles-Osoria

jatiles@illinois.edu

1 Department of Sociology, University of Illinois at Urbana-Champaign, 3080 Lincoln Hall, 702 S. Wright St. (MC454), Urbana, IL 61801, USA 
Thus, law and legality become central to the reflection on how to avoid ecological catastrophe.

The book engages with a transnational legal history of corporate power and elucidates the legal design and political projects behind ecocide. Based on a solid sociolegal research methodology combining legal history, critical legal studies and crimes of the powerful approaches, and sophisticated archival analysis, the book is divided into three chapters.

Chapter one, What is the Corporation?, engages in a critical analysis of the corporation's legal ontogenesis as dispositive of capitalist accumulation. The chapters emphasize how corporate legal personhood has been developed in both Common and international law. Whyte systemically depicts the development of legal personhood through the analysis of corporation's rights, privileges and responsibilities.

One salient aspect of corporate legal personhood is immortality, as shown by the example of Stora Kopparberg, a Swedish mining company founded in 1288, used throughout the book. Now known as Stora-Enso, a paper company based in Finland, this corporation illustrates the ever-increasing and mutable legal nature of corporate power. Structures of irresponsibility are an additional example of corporate rights and privileges. These structures are possible through the process of financialization that allows for the radical separation between corporate actions and its shareholders. Known as limited liability and corporate veil, corporations can externalize the cost of environmental damage and legal liability while shielding shareholders and investors of any responsibility. This legal design of the corporation has enabled criminogenic and ecocidal practices as part of the corporation's DNA.

Chapter two, From colonialism to ecocide: capital's insatiable need to destroy, provides a historical understanding of the corporation as part of Western modernity and imperialism. Whyte convincingly shows that corporations were central to European colonialism and the transatlantic enslaved trade. Furthermore, corporate violence and plunder did not end with colonialism, but rather it has become an essential part of neocolonial and neoliberal economics. Whyte describes the continuation of the colonial past of the corporation and its proclivities to the destruction of the environment. This is clearly shown by how the global economy, tax-havens, and supply chains have been structured to serve profiteering at the hands of few Global North corporations.

Chapter three, Regulation at the endpoints of the world, engages in a discussion of the different legal alternatives and forms of regulation designed to curtail the power of corporations. This chapter shows how these regulations target individuals, ignoring ecocidal tendencies, the legal constitution and design of the corporation. Whyte argues that we cannot simplistically describe all of the energy that the government has spent in the neoliberal period to assist business as "deregulation". Rather, it is re-regulation. There is no "roll-back" of the state at work; the state is merely involved in different types of regulations. Three legal forms in which re-regulation takes place are: corporate self-regulations; limiting the capacity of regulators to enforce environmental and health protections; and the corporate veil.

The concept of the political economy of speed is key to understanding the capitalist dynamics of profit-making beyond any safety limits and regulations. Whyte argues that the concept describes how political strategies interact with economic conditions to shape the speed and intensity of production regimens. The author adds, "the important thing to grasp about this way of understanding industrial processes is that governments 
are never powerless. They always influence both economic and industrial outcomes" (Whyte, 2020, 123). Entwined with the political economy of speed, financialization is an essential aspect of how corporations engage in ecocide. As Whyte argues, "the corporation's core purpose is realized in the transformation of social relationships into financial relationships" (Whyte, 2020, 63).

In the Conclusion, Whyte begins by criticizing what he calls Green Market Fetishism, and individual solutions to ecocide, and then proposes a series of alternatives to current corporate practices. One of these alternatives consists of controlling the starpoint, limiting the extraction of raw materials and preventing the manufacture of harmful products. Against the commonly proposed alternative such as fines and death penalties for the corporations that always end up affecting workers and communities and not shareholders and investors, Whyte proposes: breaking the corporate structure; ending impunity for investors and shareholders; and ending impunity for corporate executives. In the end, Whyte mobilizes a modest proposal: Kill the corporation before it kills us.

It is precisely at the outset of this proposal that, even though the book does not engage with a decolonial approach to the corporation and corporate law, the reader can identify that killing the corporation and resisting ecocide are embedded in a larger decolonial project. That is, abolishing western-capitalist and legal structures that make the corporation possible in the first place. Therefore, thinking about the possibility of killing the corporation as a privileged method of economic production entails a decolonial project that emphasizes reparations and justice for the victims of colonialism and enslavement. These historical processes that still haunt us (as the BLM mobilizations attested) were made possible through the legal structures of corporate capitalism. Thus, this project entails abandoning the legal, epistemic, and economic structures that made the corporation possible.

Publisher's Note Springer Nature remains neutral with regard to jurisdictional claims in published maps and institutional affiliations. 